\title{
EVALUATION OF IN VITRO ANTIDIABETIC ACTIVITY OF METHANOLIC EXTRACT OF SEAGRASS HALOPHILA BECCARII
}

\author{
VANI M, VASAVI T, UMA MAHESWARI DEVI P*
}

Department of Biochemistry and Applied Microbiology, Sri Padmavati Mahila Visvavidyalayam, Tirupati, Andhra Pradesh, India. Email: Umadevi66@gmail.com

Received: 09 March 2018, Revised and Accepted: 23 April 2018

\section{ABSTRACT}

Objectives: The objectives of this study were to analyze the in vitro antidiabetic activity of methanolic extract of seagrass.

Methods: The methanolic extract of Halophila beccarii was tested for its in vitro antidiabetic potential through inhibition of carbohydrate digestive enzymes such as $\alpha$ - amylase and $\alpha$-glucosidase, glucose diffusion assay, glucose adsorption capacity, and enhancement of glucose uptake activity in yeast cells.

Results: The crude extract of $H$. beccarii showed strong inhibition of a-amylase and a-glucosidase as on comparison with the standard enzyme inhibitor acarbose. The antidiabetic activity was found to be concentration dependent, and the antihyperglycemic activity was demonstrated through the inhibition of the glucose movement and facilitated diffusion of glucose. The rate of glucose diffusion across the membrane was found to be increased from 30 to $180 \mathrm{~min}$.

Conclusion: The seagrass collected from Pulicat Lake was identified as $H$. beccarii based on the morphology of the plant, shape of the leaves, and brown pigmentation on the leaves. According to the results, $H$. beccarii showed antidiabetic activity by the inhibition of carbohydrate digestive enzymes and glucose movement; hence, it is significantly reduced the post-postprandial hyperglycemia.

Keywords: Seagrass, Halophila beccarii, Facilitated diffusion, a-Amylase, a-Glucosidase, Antidiabetic, Carbohydrates.

(C) 2018 The Authors. Published by Innovare Academic Sciences Pvt Ltd. This is an open access article under the CC BY license (http://creativecommons. org/licenses/by/4. 0/) DOI: http://dx.doi.org/10.22159/ajpcr.2018.v11i8.25752

\section{INTRODUCTION}

Diabetes mellitus is a chronic metabolic disorder due to the deficiency of insulin or resistance to the insulin, and further, it leads to macrovascular and microvascular diseases [1]. The strategic treatment for diabetes mainly focuses on stimulation of endogenous insulin secretion and enhancement of insulin action on target tissue and also to inhibit the degradation of oligo- and disaccharides [2,3]. The majority of the synthetic drugs are targeted toward the inhibition of carbohydrate digestive enzymes such as $\alpha$-glucosidase and $\alpha$-amylase. The $\alpha$-glucosidase catalyzes the breakdown of oligo- and/ or disaccharides into monosaccharides, and the inhibition of these enzymes reduces blood glucose levels by interfering the absorption of monosaccharides through the mucosal border in the small intestine. Similarly, the inhibition of $\alpha$-amylases delays the absorption of glucose and thereby controls the serum glucose levels [4].

Currently, herbal medicines are getting more importance in the treatment of diabetes $[5,6]$. The seagrass plants are a group of marine hydrophilus angiosperms live in an estuarine or in the marine environment. The seagrass is reported to be widely used in the folklore medicine as sedatives and for the treatment of wounds and fever [7]. Thus, in this study, the seagrass was chosen to investigate its effect on $\alpha$-amylase and $\alpha$-glycosidase inhibitory activities and glucose homeostasis. The novelty of this work is, in vitro studies have not been studied earlier. And also, this complete research study is a new work done on seagrass, i.e., Halophila beccarii species as no one had prior studies.

\section{METHODS}

\section{Collection of seagrass sample}

The seagrass plants were collected from sea coast near Pulicat Lake at Nellore district, AP, India. The seagrass plant was botanically identified as $H$. beccarri belongs to Hydrocharitaceae family. The collected plants were brought to laboratory under aseptic conditions and washed with tap water and distilled water. The washed material was shade dried, and the dried samples were then ground to fine powder using mixer grinder.

\section{Preparation of extract}

About $20 \mathrm{~g}$ dry powder of $H$. beccarii was soaked in $200 \mathrm{ml}$ of methanol for about 1 week. The solution was then filtered using a Whatman No. 1 filter paper, and the extract was evaporated to dryness with Rota evaporator model under reduced pressure at $40^{\circ} \mathrm{C}$. The dried methanolic extract was dissolved in $0.1 \%$ dimethyl sulfoxide (DMSO) and stored at $4^{\circ} \mathrm{C}$ for further use.

\section{Inhibition of $\alpha$-amylase activity}

The effect of extract on the inhibition of $\alpha$-amylase activity was measured by 3,5-dinitro salicylic acid (DNS) method using starch as a substrate [8]. Briefly, $10 \mathrm{mg}$ of pancreatic $\alpha$-amylase was dissolved to $10 \mathrm{ml}$ of distilled water and substrate solution was prepared by mixing starch (1\%) with $20 \mathrm{mmol}$ phosphate buffer ( $\mathrm{pH}$ 6.9) and $\alpha$-amylase activity was calculated based on the decreased levels of maltose. The reaction was initiated with the addition of different concentrations (100-500 $\mu \mathrm{g}$ ) of extract of $H$. beccarii and $100 \mu \mathrm{l}$ of $\alpha$-amylase to $400 \mu \mathrm{l}$ of starch solution. The reaction mixture was incubated at $37^{\circ} \mathrm{C}$ for about $10 \mathrm{~min}$. After incubation, the reaction was terminated by adding $100 \mu \mathrm{l}$ of DNS reagent ( $96 \mathrm{mmol}$ DNS and $30 \mathrm{~g}$ sodium potassium tartrate in 0.5 $\mathrm{M} \mathrm{NaOH}$ ) and placed in water bath at $60^{\circ} \mathrm{C}$. After $15 \mathrm{~min}$, this mixture was diluted with $900 \mu \mathrm{l}$ distilled water, and $\alpha$-amylase inhibition was determined by measuring absorbance at $540 \mathrm{~nm}$. Control was maintained by replacing the extract with DMSO (0.1\%). The percentage of $\alpha$-amylase inhibition was calculated.

\section{Inhibition of $\alpha$-glucosidase activity}

The $\alpha$-glucosidase inhibitory activity of extract of $H$. beccarii was studied as per the method of Suthindhiran et al. [9]. The reaction mixture containing 
different concentrations of extract ranging from $100 \mu \mathrm{g}$ to $500 \mu \mathrm{g}, 50 \mu \mathrm{l}$ of phosphate buffer (100 mmol), $\mathrm{pH} 6.8$, and $100 \mu \mathrm{l} \alpha$-glucosidase $\left(1 \mathrm{U} / \mathrm{ml}\right.$ ) was preincubated at $37^{\circ} \mathrm{C}$ for about $15 \mathrm{~min}$. After preincubation, the reaction mixture was treated with $50 \mu \mathrm{l}$ of P-nitrophenyl $\alpha$-D glucopyranoside in $5 \mathrm{mmol}$ in phosphate buffer $\mathrm{pH} 6.8$ and incubated at $37^{\circ} \mathrm{C}$ for $20 \mathrm{~min}$. Finally, the reaction was terminated with $50 \mu \mathrm{l}$ of $\mathrm{Na}_{2} \mathrm{CO}_{3}$. The absorbance of yellow color para-nitrophenol released from PNPG was measured at $405 \mathrm{~nm}$. Control was maintained without methanolic extract. The percentage inhibition of a-glucosidase activity was calculated.

\section{Determination of glucose adsorption capacity}

Glucose adsorption capacity of the extract was calculated as per the standard method of Ou et al. [10]. About $1 \mathrm{ml}$ of the extract of $H$. beccarii was added to $25 \mathrm{ml}$ of glucose solution in different concentrations ranging from 5 to $100 \mathrm{mmol}$ and incubated in shaker water bath at $37^{\circ} \mathrm{C}$ for about $6 \mathrm{~h}$. After incubation, the reaction mixture was centrifuged at $4800 \mathrm{rpm}$ for $20 \mathrm{~min}$, and the residual glucose of the supernatant was measured. Metronidazole used as a control standard. The concentration of bound glucose was calculated using the following formula.

$$
\text { Glucose bound }=\frac{\mathrm{G} 1-\mathrm{G} 6}{\text { Weight of the sample }} \times \text { Volume of glucose }
$$

\section{G1 - Glucose concentration of original solution}

G6 - Glucose concentration after $6 \mathrm{~h}$.

\section{Glucose diffusion assay}

The diffusion of glucose, in the presence of extract of $H$. beccarii, was assessed using dialysis model by Edwards et al. [11], Ahmed et al. [12]. The experimental setup was made by loading $1 \mathrm{ml}$ of extract $(500 \mu \mathrm{g} / \mathrm{ml})$ and $1 \mathrm{ml}$ of glucose solution $(20 \mathrm{~mm}$ in $0.15 \mathrm{M} \mathrm{Nacl})$ into the dialysis bag (12000 MW, Hi-Media laboratory). The dialysis bag was sealed at both ends and placed in a $200 \mathrm{ml}$ of beaker containing $45 \mathrm{ml}$ of $0.15 \mathrm{M} \mathrm{NaCl}$. The control bag was loaded with $1 \mathrm{ml}$ of $0.15 \mathrm{M} \mathrm{Nacl}, 20 \mathrm{~mm}$ glucose, and $1 \mathrm{ml}$ distilled water. The quantity of glucose in the external solution was measured. The beaker was placed in orbital shaker at room temperature $\left(20 \pm 2^{\circ} \mathrm{C}\right)$. All tests were carried out in triplicate, and the concentrations of glucose were estimated using the 0-Toluidine method.

\section{Uptake of glucose by yeast cells}

Different concentrations of extract of $H$. beccarii (1-5 mg) were added to $1 \mathrm{ml}$ of glucose solution (5-25 mmol/L) and preincubated for $10 \mathrm{~min}$ at $37^{\circ} \mathrm{C}$. The reaction was initiated by the addition of $100 \mu \mathrm{l}$ of yeast cell suspension according to the method of yeast cells [13], mixed well and incubated at $37^{\circ} \mathrm{C}$ for $60 \mathrm{~min}$. After incubation, the tubes were centrifuged at $3800 \mathrm{rpm}$ for $5 \mathrm{~min}$ and the supernatant was collected and the absorbance was measured at $620 \mathrm{~nm}$. Metformin was used as a standard. The percent of glucose uptake by yeast cells was calculated on comparison with control sample [14].

\section{RESULTS}

The seagrass collected from Pulicat Lake was identified as $H$. beccarii based on the morphology of the plant and shape of the leaves Fig. 1. The present study focused on detecting the ability of $H$. beccarii to serve as an effective antidiabetic agent. The whole plant of $H$. beccarii was extracted with methanol and extract was dissolved in $0.1 \%$ DMSO and analyzed for in vitro antidiabetic activity.

The extract showed a percentage inhibition of $30.2 \pm 0.25$ and $75.1 \pm 0.07$ at $100 \mu \mathrm{g} / \mathrm{ml}$ and $500 \mu \mathrm{g} / \mathrm{ml}$, respectively. The $\mathrm{IC}_{50}$ value of extract was found to be at $270 \mu \mathrm{g} / \mathrm{ml}$, whereas IC I0 $_{50}$ value of acarbose was observed at $183 \mu \mathrm{g} / \mathrm{ml}$; the result was given in Table 1 . Acarbose is a standard antidiabetic drug and it is competitively and reversibly inhibiting the pancreatic a-amylase.

$\alpha$-Glucosidase activity is the hallmark to indicate the state of diabetes. The extract of $H$. beccarii exhibited prominent inhibitory action on $\alpha$-glucosidase. The concentration-based inhibition was noticed with a percentage inhibition of $50 \%$ and $90 \%$ at $100 \mu \mathrm{g} / \mathrm{ml}$ and $500 \mu \mathrm{g} / \mathrm{ml}$ of extract, respectively, and $\mathrm{IC}_{50}$ was found at $100 \mu \mathrm{g} / \mathrm{ml}$. On the other hand, the standard acarbose exhibited $50 \%$ inhibition of $\alpha$-glucosidase at $75 \mu \mathrm{g} / \mathrm{ml}$, and the obtained results were represented in Table 2 .

The glucose adsorption capacity of extract was investigated, and the results were presented in Fig. 2. The adsorption of glucose was noticed at all concentrations of extract, and the binding capacity was found to be proportional to the molar concentration of glucose.

A simple dialysis model was used to determine the glucose diffusion inhibition by $H$. beccarii. After $3.0 \mathrm{~h}$ of dialysis, the movement of glucose from the control sample reached a peak level, and the concentration in the external solution was $18.3 \pm 0.3 \mathrm{mmol} / \mathrm{l}(5.3 \%)$ Fig. 3 . H. beccarii extract $500 \mu \mathrm{g} / \mathrm{ml}$ was used to analyze time-dependent impact on glucose diffusion. The glucose diffusion was significantly decreased after $60 \mathrm{~min}$ and external glucose concentration was $1.4 \pm 0.3 \mathrm{mmol} / \mathrm{L}$. After $3 \mathrm{~h}$ of dialysis, the overall $71 \%$ decrease in total glucose diffusion compared to control.

Glucose concentrations inside the dialysis tubing were reciprocally coupled to the glucose concentrations in the external solution (control, $1.7 \pm 1.21 \mathrm{mmol} / \mathrm{L}$ and $18.6 \mathrm{mmol} / \mathrm{L}$ in extract). The proportion of glucose transport across the cell membrane of yeast cells was studied in an in vitro system consisting of different concentrations of extract of $H$. beccarii $(1-5 \mathrm{mg} / \mathrm{ml})$ and glucose ranging from 5 to $25 \mathrm{mmol} / \mathrm{L}$.

The percentage of glucose uptake by yeast cells increases with increase in the concentration of extract of $H$. beccarii Fig. 4. The amount of residual glucose in the sample after a specific time serves as an indicator of the glucose uptake by the yeast cells. At lower concentration, i.e., $1 \mathrm{mg} / \mathrm{ml}$, the percentage of glucose uptake was $30 \pm 0.20$ initiated but as concentration increases the percentage of uptake reached maximum $75 \pm 0.32$.

\section{DISCUSSION}

The digestion of starch begins in the mouth with the catalytic fusion of $\alpha$-amylase secreted in saliva. The process of digestion is continued

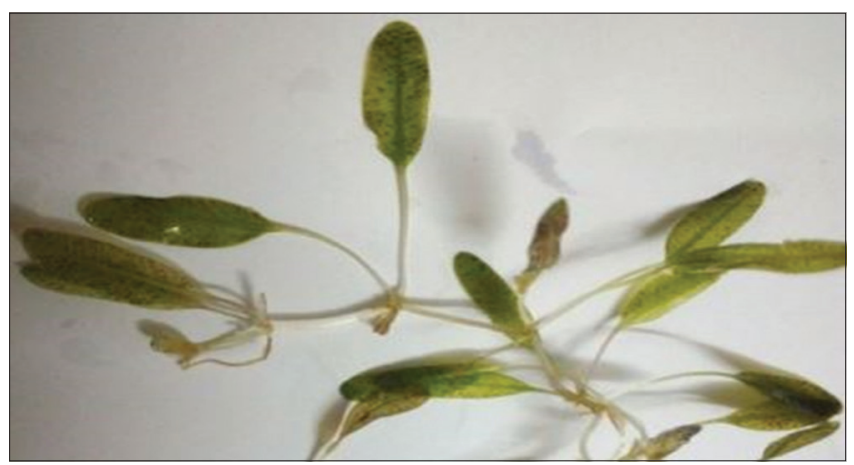

Fig. 1: Seagrass Halophila beccarii

Table 1: Percentage of inhibition of a-amylase activity

\begin{tabular}{llll}
\hline Sample & Concentration $\boldsymbol{\mu g} / \mathbf{m l}$ & $\begin{array}{l}\text { \% of } \\
\text { inhibition }\end{array}$ & $\mathbf{I C}_{\mathbf{5 0}} \boldsymbol{\mu g} / \mathbf{m l}$ \\
\hline Methanolic & 100 & $50.30 \pm 0.03$ & \\
extract of & 200 & $60.03 \pm 0.02$ & \\
seagrass & 300 & $70.03 \pm 0.02$ & \\
& 400 & $78.02 \pm 0.07$ & \\
& 500 & $90.02 \pm 0.07$ & $270 \mu \mathrm{g} / \mathrm{ml}$ \\
Acarbose & 100 & $45.30 \pm 0.02$ & \\
standard & 200 & $68.02 \pm 0.44$ & \\
& 300 & $72.22 \pm 0.20$ & \\
& 400 & $75.40 \pm 0.08$ & \\
& 500 & $85.01 \pm 0.05$ & $183 \mu \mathrm{g} / \mathrm{ml}$ \\
\hline
\end{tabular}

Values are expressed as mean \pm SEM of three independent experiments, statistical significance $1 \%$ level $(\mathrm{p} \leq 0.01)$. SEM: Standard error of the mean 
Table 2: Percentage of inhibition of a-glucosidase activity

\begin{tabular}{llll}
\hline Sample & Concentration $\boldsymbol{\mu g} / \mathbf{m l}$ & $\begin{array}{l}\text { \% of } \\
\text { inhibition }\end{array}$ & IC $_{\mathbf{5 0}} \boldsymbol{\mu g} / \mathbf{m l}$ \\
\hline Methanolic & 100 & $30.02 \pm 0.25$ & \\
extract of & 200 & $40.07 \pm 0.56$ & \\
seagrass & 300 & $55.03 \pm 0.12$ & \\
& 400 & $68.02 \pm 0.07$ & \\
& 500 & $75.02 \pm 0.08$ & $100 \mu \mathrm{g} / \mathrm{ml}$ \\
Acarbose & 100 & $60.03 \pm 0.02$ & \\
standard & 200 & $68.02 \pm 0.04$ & \\
& 300 & $75.05 \pm 0.02$ & \\
& 400 & $82.07 \pm 0.08$ & \\
& 500 & $95.01 \pm 0.05$ & $75 \mu \mathrm{g} / \mathrm{ml}$ \\
\hline
\end{tabular}

Values are expressed as mean \pm SEM of three independent experiments, statistical significance $1 \%$ level $(\mathrm{p} \leq 0.01)$. SEM: Standard error of the mean

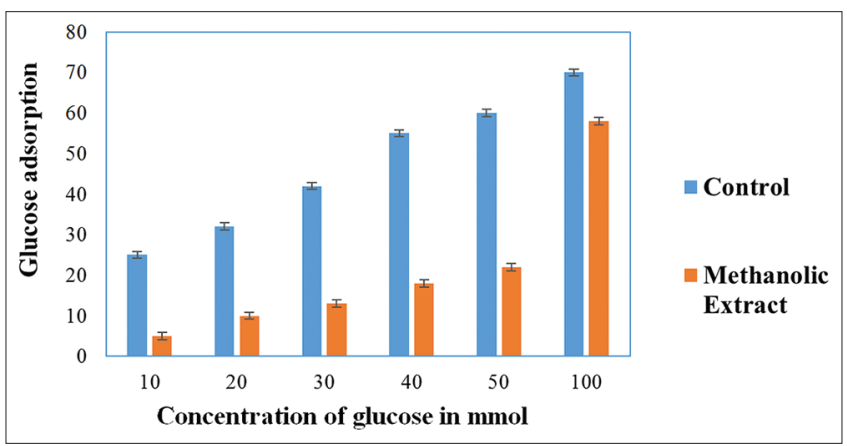

Fig. 2: Effect of Halophila beccarii extract on adsorption of glucose. Values are expressed as mean \pm standard error of the mean of three independent experiments, statistical significance $1 \%$ level $(\mathrm{p} \leq 0.01)$

in the intestine due to the production of $\alpha$-amylase. The extract of $H$. beccarii showed tremendous effect on the inhibition of $\alpha$-amylase and $\alpha$-glucosidase enzymes. Therefore, it reduces the digestion of complex carbohydrates and reduces absorption of glucose which further results in the reduction of blood glucose concentration. $\alpha$-Glucosidase, located in the intestinal lumen and brush border membrane of intestine, is actively engaged in the digestion of polysaccharides and disaccharides before their absorption [15]. Acarbose, a complex oligosaccharide, is a structural analog of starch and competitively inhibits $\alpha$-glucosidase which delays the digestion of starch and disaccharides. Thus, the inhibition of $\alpha$-glucosidase is an ideal therapeutic approach to decrease the absorption of carbohydrates [16]. This study provides an alternative natural product from seagrass with hyperbolic potency and lesser side effects than present synthetic drugs. The inhibition of $\alpha$-amylase and $\alpha$-glucosidase may lead to reduction in postprandial hyperglycemia which is an important risk factor for cardiovascular diseases [17]. Thus, the inhibition of $\alpha$-amylase and $\alpha$-glucosidase is important to control post-postprandial hyperglycemia in the treatment of diabetes. The extract was more effective in adsorbing glucose at both lower and higher concentrations which further reduces the amount of glucose transport across the intestinal lumen. The data clearly projects that $H$. beccarii is potential in arresting the glucose diffusion which further confirms that the $H$. beccarii is capable of regulating the movement of glucose out of the cells into bloodstream and thus control the postpostprandial glucose levels [18] reported the inhibitory activity of medicinal plants against glucose diffusion. Uptake of glucose by yeast is widely used screening method for evaluating the antidiabetic activity of natural products. Yeast cells take up glucose by facilitated diffusion. In this process effective transport of extracellular glucose into the cells is attained through carriers that transport solutes down the concentration gradient.

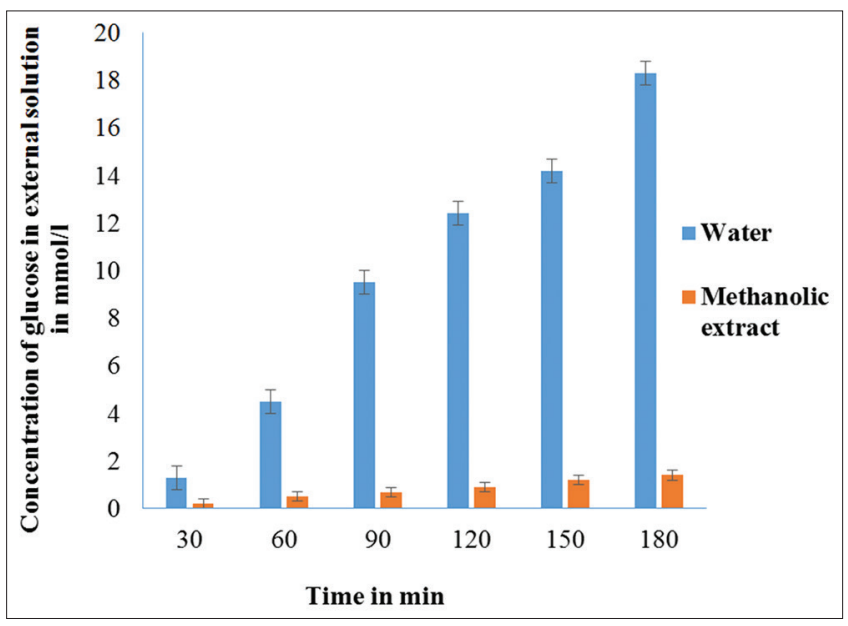

Fig. 3: Effect of Halophila beccarii extract on diffusion of glucose. Values are expressed as mean \pm standard error of the mean of three independent experiments, statistical significance $1 \%$ level (ps0.01).

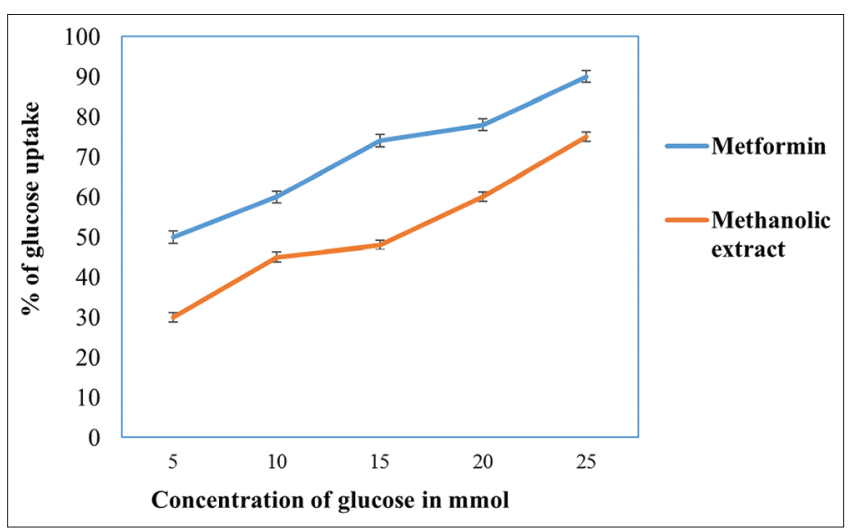

Fig. 4: Effect of Halophila beccarii extract on uptake of glucose by yeast cells. Values are expressed as mean \pm standard error of the mean of three independent experiments, statistical significance $1 \%$ level $(\mathrm{p} \leq 0.01)$

For treating diabetes, in the traditional Indian Ayurvedic system, there are several medicinal plants and their formulations are available as well as in ethnomedicinal practices as their principal bioactive components showed good a-amylase inhibitory activity [19].

In vitro analysis of the antidiabetic activity of seagrass is in accordance with the previous study of medicinal plants, wherein there is a positive relationship between the total polyphenol and flavonoid content and the ability to inhibit intestinal $\alpha$-glucosidase and pancreatic $\alpha$-amylase $[20,21]$. Up to now, no reports are available on in vitro antidiabetic of seagrass.

\section{CONCLUSION}

The present study is the first report on validating the antidiabetic activity of $H$. beccarri using appropriate in vitro techniques. The study provides the possible mechanism of glucose lowering activity of $H$. beccarii which was explained through inhibition of $\alpha$-amylase, $\alpha$-glucosidase, and glucose movement, diffusion of glucose across cell membrane and by increasing glucose adsorption.

\section{ACKNOWLEDGMENT}

The authors are much thankful to CURIE facilities, Sri Padmavati Mahila Visvavidyalayam for the experimental analysis. 


\section{AUTHORS' CONTRIBUTIONS}

Concept and collection of data - Vani. M. Writing the article and critical review of the article - Vani. M and Vasavi. T. Final approval of the article - Prof P. Uma Maheswari Devi.

\section{CONFLICTS OF INTEREST}

Nil.

\section{REFERENCES}

1. Keerthana G, Kalaivani MK, Sumathy A. In-vitro alphaamylase inhibitory and anti-oxidant activities of ethanolic leaf extract of croton bonplandianum. Asian J Pharm Clin Res 2013;6:32-6.

2. Groop L, Forsblom C, Lehtovirta M. Characterization of the prediabetic state. Am J Hypertens 1997;10:172-80.

3. Perfetti R, Barnett PS, Mathur R, Egan JM. Novel therapeutic strategies for the treatment of Type 2 diabetes. Diabetes Metab Rev 1998;14:207-25.

4. Dineshkumar B, Mitra A, Manjunatha MA. Comparative study of alpha amylase inhibitory activities of common antidiabetic plants of Kharagpur 1 block. Int J Green Pharm 2010;4:115-21.

5. Grover JK, Yadav S, Vats V. Medicinal plants of India with antidiabetic potential. J Ethnopharmacol 2002;81:81-100.

6. Mukherjee PK, Maiti K, Mukherjee K, Houghton PJ. Leads from Indian medicinal plants with hypoglycemic potentials. J Ethnopharmacol 2006; 106:1-28.

7. Newmaster AF, Berg KJ, Ragupathy S, Palanisamy M, Sambandan K, Newmaster SG, et al. Local knowledge and conservation of seagrasses in the Tamil Nadu State of India. J Ethnobiol Ethnomed 2011;7:37.

8. McCue PP, Shetty K. Inhibitory effects of rosmarinic acid extracts on porcine pancreaticamylase in vitro. Asia Pac J Clin Nutr 2004;13:101-6.

9. Suthindhiran KR, Jayasri MA, Kannabiran K. $\alpha$-glucosidase and $\alpha$-amylase inhibitory activity of Micromonospora sp. VITSDK3(EU551238). Int J Integr Biol 2009;6:115-20.

10. Ou S, Kwok K, Li Y, Fu L. In vitro study of possible role dietary fibre in lowering postprandial serum glucose. J Agric Food Chem
2001;49:1026-9.

11. Edwards CA, Johnson IT, Read NW. Do viscous polysaccharidesslow absorption by inhibiting diffusion or convection? Eur J Clin Nutr 1988;42:307-12.

12. Ahmed F, Sairam S, Urooj A. In vitro hypoglycemic effects of selected dietary fiber sources. J Food Sci Technol 2011;s48:285-9.

13. Daksha G, Chandrashekher K, Pal G. In vitro antidiabetic activity of pentacyclic tritrprnoida and fatty acid ester from Bauhinia purpurea. Int J Pharm Technol 2013;2:2277-3436.

14. Cirillo VP. Mechanism of glucose transport across the yeast cell membrane. Bacteriology 1962;84:485-91.

15. Lee HS. Inhibitary activity of Cinnamomum cassia bark derived component against rat lens aldolase reductase. J Pharm Pharm Sci, 2002;5;226-30.

16. Conforti F, Statti G, Loizzo MR, Sacchetti G, Poli F, Menichini F, et al. In vitro antioxidant effect and inhibition of alpha-amylase of two varieties of amaranthus caudatus seeds. Biol Pharm Bull 2005;28: 1098-102.

17. Ceriello A, Cavarape A, Martinelli L. The post-prandial state in Type 2 diabetes and endothelial dysfunction: Effects of insulin aspart. Diabet Med 2004;21:171-5.

18. Gallagher AM, Flatt PR, Duffy G, Abdel-Wahab YH. The effects of traditional ant diabetic plants on in vitro glucose diffusion. Nutr Res 2003;23:413-24.

19. Kunyanga CN, Imungi JK, Okoth MW, Biesalski HK, Vadivel V. Total phenolic content, antioxidant and antidiabetic properties of methanolic extract of raw and traditionally processed Kenyan indigenous food ingredients. LWT Food Sci Technol 2012;45:269-76.

20. Mai TT, Thu NN, Tien PG, Van Chuyen N. Alpha-glucosidase inhibitory and antioxidant activities of Vietnamese edible plants and their relationships with polyphenol contents. J Nutr Sci Vitaminol (Tokyo) 2007:53:267-76

21. Ramkumar KM, Thayumanavan B, Palvannan T, Rajaguru P. Inhibitory effect of Gymnema montana leaves on $\alpha$-glucosidase activity and $\alpha$-amylase activity and their relationship with polyphenolic content. Med Chem Res 2010;19:948-61. 